\title{
外科的矯正治療における治療予測と治療結果の比較：骨格性上顎前突
}

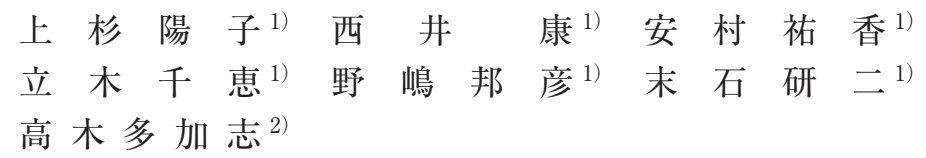

\section{A Comparison between Treatment Prediction and Outcome in Orthognathic Surgery: Skeletal Maxillary Protrusion}

\author{
YoKo UESUGI ${ }^{1)}$, YASUSHI NISHII ${ }^{1)}$, YUKa YASUMURA ${ }^{1)}$, \\ CHIE TACHIKI $^{1)}$, Kunihiko NOJIMA ${ }^{1)}$, KenJI SUEISHI ${ }^{1)}$ \\ and TAKASHI TAKAKI ${ }^{2)}$
}

\begin{abstract}
Objective: This study aimed to confirm the usefulness of cephalometric prediction $(\mathrm{CP})$ in the diagnostic and treatment planning stages of surgical-orthodontic treatment. Few reports have been published on the prediction accuracy of manual $\mathrm{CP}$ and it has not been sufficiently investigated. Therefore, this study compared treatment predictions based on manual $\mathrm{CP}$ and treatment outcomes in cases of skeletal maxillary protrusion.

Methods: The subjects were 28 patients with skeletal maxillary protrusions who underwent orthodontic treatment at Tokyo Dental College Chiba Hospital. Subjects were divided into the following two groups: patients treated surgically with sagittal split ramus osteotomy (SSRO) only (1-jaw group; $\mathrm{n}=13$ ), and patients who underwent both SSRO and Le Fort I osteotomy (2-jaw group; $\mathrm{n}=15)$. Distances and angles were measured and compared between manual $\mathrm{CP}$ prepared from lateral cephalograms taken at the initial examination and lateral cephalograms at the completion
\end{abstract}

of treatment.

Results: Tests of the difference in the predicted amount of movement and the actual movement revealed no significant differences in the 1-jaw group, and no significant differences except for Gonion in the 2-jaw group. The predicted positioning and actual positioning resulting from treatment were also compared. In the maxilla, no significant differences were seen between the treatment predictions and surgical results in the 2 -jaw group. In the mandible, there were no significant differences in both the 1-jaw and 2-jaw groups.

Conclusion: Manual CP accurately predicted the positioning of the maxillary and mandibular bones in surgical-orthodontic treatment for skeletal maxillary protrusion, and is useful both at diagnosis and when establishing a treatment plan.

Key words : orthognathic surgery（外科的矯正治療）, cephalometric prediction, skeletal maxillary protrusion (骨格性上顎前突)

[Received Jul. 11, 2014]

\footnotetext{
1) 東京歯科大学千葉病院歯科矯正学講座 (主任 : 末石研二教授)

2) 東京歯科大学口腔外科学講座（主任 : 柴原孝彦教授）

1) Department of Orthodontics, Tokyo Dental College (Chief: Prof. Kenji SUEISHI)

2) Department of Oral and Maxillofacial Surgery, Tokyo Dental College (Chief: Prof. Takahiko SHIBAHARA)
} 


\section{緒言}

外科的矯正治療の目的は機能と審美性の改善, および正 常で安定した咬合を得ることである。外科的矯正治療を成 功に導く 2 つ要因として適切な治療計画と口腔外科医が 治療計画に沿った治療を施行することが挙げられる ${ }^{1-5)} 。$

適切な治療計画立案において側貌頭部 X 線規格写真を 用いた cephalometric prediction (CP) の利用が有用とさ れている。CP の前身としては，1970 年代に Ricketts が側 貌頭部 X 線規格写真をコンピュー夕処理し, 診断や治療 計画, 成長予測に加え, 外科的治療にも利用したことが挙 げられ ${ }^{6,7)}, 1980$ 年代以降には Wolford により側貌頭部 X 線規格写真のトレースを行い, そのトレースに顎矯正手術 前の予測トレース, 顎矯正手術後の予測トレースを重ね合 わせる手用 $\mathrm{CP}$ が発表されている8)。近年ではデジタル化 が進み, コンピュータ上の処理で顎矯正手術の治療予測を 行うことが可能となっている。さらにデジタルカメラやデ ジタルレントゲンシステムとの連携や, 手術時に用いるス プリント製作など多岐にわたりソフトウェアの開発が進ん でいる ${ }^{9)}$ 。

デジタルトレースやデジタルプレディクションを用いた ソフトウェアによる CP の精度を検討する文献は数多く発 表されている ${ }^{9)}$ 。それらの研究は上下顎において下顎枝や 下顎角の計測項目を除き有意差は無く, 良好な治療予測精 度が確認され, 治療計画立案や手術時の位置づけに有用と 述べている10-19)。

しかし, 日常臨床において矯正歯科医が初診時の診断に おいて $3 \mathrm{D}$ シミュレーションを行う機会は未だ少なく, 手

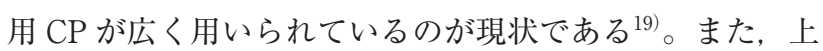
記の報告は, 顎矯正手術における手術精度に対してであ り, 一連の外科的矯正治療において, 初診時の治療予測か ら術前矯正治療それに続く顎矯正手術, 術後矯正治療を通 じての治療予測精度を検討した報告は行われていない。

矯正歯科医は, 初診時 CPにより治療終了時を予測しそ の結果によって, 治療方針を決定する。すなわち初診時 $\mathrm{CP}$ が実際の治療終了時と一致しているかどうか, その精 度は治療方針の選択に多大な影響を及ぼす。

そこで本研究は, 下顎後退による骨格性上頂前突症に対 し, 術前資料から立案した手用 CPによる治療予測と治療 結果を比較し, その予測精度について検討することを目的 とした。

\section{研究方法}

\section{1. 研究対象ならびに資料}

対象は, 東京歯科大学千葉病院にて 2000 年から 2011 年 の間に外科的矯正治療を施行した下顎後退による骨格性 上顎前突症患者 28 症例とした。手術術式により, 下顎枝
矢状分割術を単独で施行した 13 症例（1jaw 群：平均年 齢 28 歳 4 力月, 男性 2 症例, 女性 11 症例, 平均 overjet $9.42 \pm 3.50 \mathrm{~mm}$, 平均 overbite $0.69 \pm 2.21 \mathrm{~mm}$ ) と, 上顎骨 にLe Fort I 型骨切り術, 下顎骨に下顎枝矢状分割術を併 用して上下顎移動術を施行した 15 症例（2jaw 群 : 平均年 齢 25 歳 10 力月, 男性 1 症例, 女性 14 症例, 平均 overjet $9.20 \pm 3.11 \mathrm{~mm}$, 平均 overbite $1.42 \pm 1.50 \mathrm{~mm}$ ）の 2 群に分 類した。

なお，口唇口蓋裂を含む先天異常症例は対象症例から除 外した。骨片固定にはチタン製もしくはポリ-L- 乳酸製の ミニプレートとスクリューを用いて semirigid fixation を 行った。

資料は初診時 (T1) の側貌頭部 X 線規格写真, それを もとに作成した $\mathrm{CP}$ ，および外科的矯正治療終了時 (T2) の 3 種類の側貌頭部 X 線規格写真のトレースを用いた。 側貌頭部 X 線規格写真撮影は, 初診時および外科的矯正 治療終了時 1 か月以内 $(1 \mathrm{jaw}$ 群では手術後平均 1 年 3 か月, $2 \mathrm{jaw}$ 群では手術後平均 1 年）に撮影され，トレースおよ び計測は，計測者間の誤差を排除するために同一計測者に より行った。

2. 研究方法

1) cephalometric prediction 作成方法

CP は，初診時側貌頭部 X 線規格写真のトレース上に術 前矯正治療予測トレースを重ね合わせ，次に顎矯正手術 予測トレースを重ね合わせて作成した（Fig. 1）。術前矯 正治療予測には, 抜歯・拡大 · Arch Length Discrepancy (ALD) · curve of spee ・ disking 量を考慮した上で術前 矯正による上下顎切歯，大臼歯の位置づけを予測した。 ALD は通法に従い, 診断用模型上にて叢生量や空隙量を ノギスにて計測するブロークンコンタクト法にて計測し た。curve of speeは, 煩側面において第二大臼歯咬頭頂 から切歯部切縁を通る直線から歯列の最陥凹部までの距離 を計測し, 左右の平均值を用いた。拡大については成人で は片側最大 $2 \sim 3 \mathrm{~mm}$ 程度を限界とし, diskingについて は tooth size ratioなども考慮した。

上記模型計測值に，上下顎の移動限界とそれに伴う軟組 織予測を考慮し, 抜歯・非抜歯の判定を含め術前矯正治療 における治療目標を設定した。

なお上顎切歯の設定は, 上下的には上顎切歯切縁が安静 時の上唇より $2 \sim 3 \mathrm{~mm}$ 下方に位置づけ，歯軸は DownsNorthwestern 基準值や Facial axis を参照し決定した。顎 矯正治療予測は, 前述の術前矯正治療予測をもとに, 側貌 の調和, 移動限界を考慮し上顎骨, 下顎骨の移動量を決定 した。その後, 軟組織の予測を行った ${ }^{8,20-21)}$ 。

2) 基準平面および計測点

本研究では, FH 平面を $\mathrm{X}$ 軸, これと直行し Nasion を通 る直線を $\mathrm{Y}$ 軸とする直交座標系上に, ANS, PNS, Point 


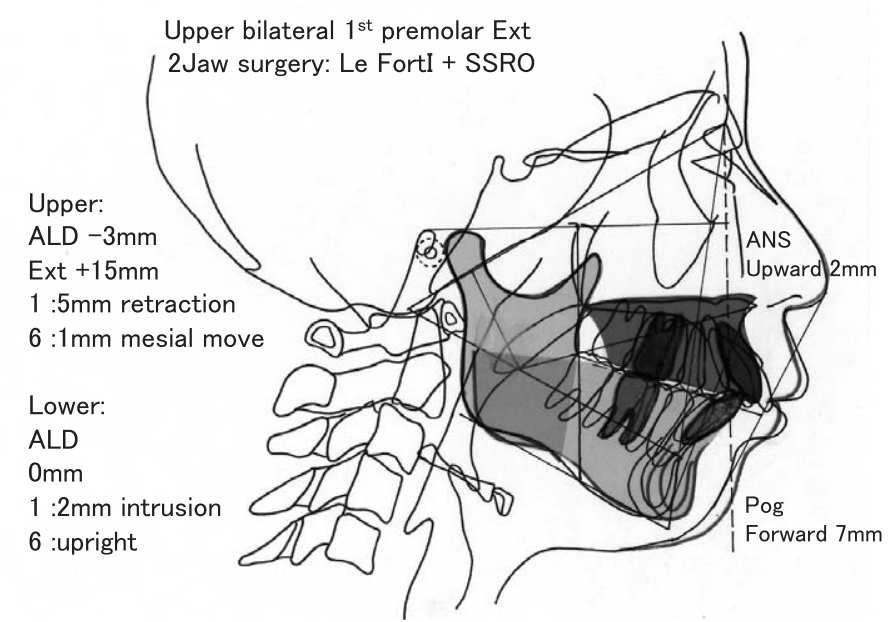

Fig. 1 Cephalometric prediction

Superimposition of the lateral cephalogram tracing at before treatment and cephalometric prediction (A case of 2jaw).

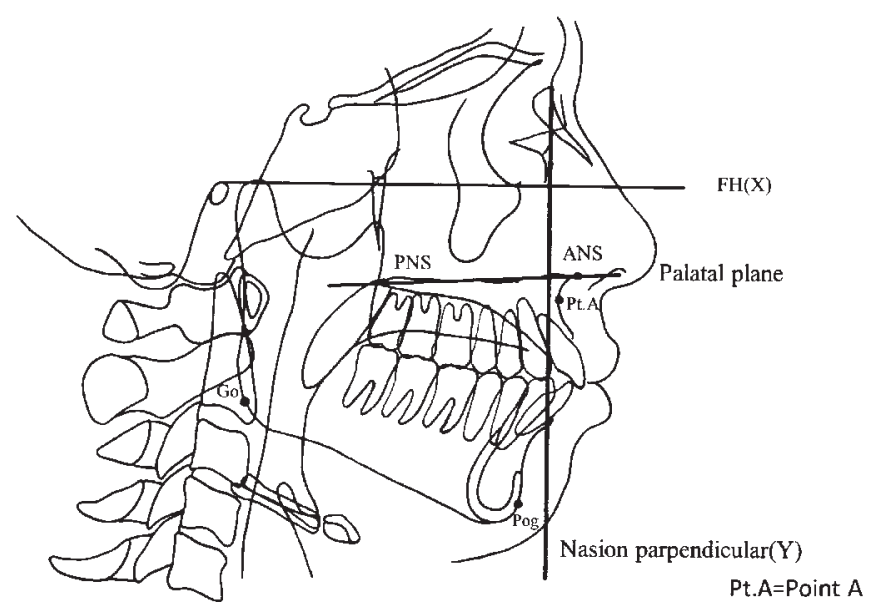

Fig. 2 Reference planes \& measuring points and plane

A, Pog, Go の硬軟組織計測点（Fig. 2) を設定した。X 軸では前方を，Y 軸では下方をそれぞれ正と定め, ANS と PNS とを結んだ palatal plane については FH 平面との なす角度を計測し, $\mathrm{FH}$ 平面より時計回りの回転を示すと き正とした ${ }^{22,23)}$ 。なお, Go は下顎枝後縁平面と下顎下縁 平面との 2 等分線が下顎角と交わる点とした。

3) 分析

1jaw 群, 2jaw 群の初診時 CP における各計測点と外科 的矯正治療終了時（T2）に扔ける各計測点の, 各平均座 標值と各標準偏差を算出し, 両群間の差をWilcoxon の符 号付順位和検定にて検定した。有意水準は $5 \%$ および $1 \%$ に設定した。

さらに，各計測点について 1 jaw 群，2jaw 群それぞれに おける $\mathrm{T} 1$ と $\mathrm{T} 2$ の差すなわち実際の治療前後での変化量 (T1-T2) と, T1 と初診時 CP (CP) との差, すなわち予 測変化量（T1-CP）を算出し, 両群間の差をWilcoxonの
符号付順位和検定にて検定した。

\section{4）誤差検定}

トレースおよび計測は, 同一計測者にて行われた。計測 誤差は, 無作為に選び出された 10 症例を異なる日に 2 回 トレースし, Dahlberg's formula $\left(\mathrm{S}^{2}=\Sigma \mathrm{D}^{2} / 2 \mathrm{~N}, \mathrm{D}: 2\right.$ 回 の測定值の差, $\mathrm{N}$ : 計測対象数) の評価法で検討した ${ }^{24)}$ 。

\section{結 果}

\section{$\mathrm{CP}$ と T2 の比較 (Table 1, Table 2)}

上顎骨に扔いて $2 \mathrm{jaw}$ 群の CP と T2 の有意差は認めな かったが, ANSにおいて CPに比べ T2 は $0.1 \mathrm{~mm}$ 後方, $1.1 \mathrm{~mm}$ 上方に位置した。PNS では CP に比べ T2 が $0.8 \mathrm{~mm}$ 前方, $0.3 \mathrm{~mm}$ 上方, Point A では CP に比べ $\mathrm{T} 2$ が $0.7 \mathrm{~mm}$, 前方 $1.8 \mathrm{~mm}$ 上方に位置した。 palatal plane については $-0.2^{\circ}$ と $\mathrm{CP}$ に比べ $\mathrm{T} 2$ の移動は $0.2^{\circ}$ 反時計回りであった。下顎 骨に拈いても両群とも有意差は認めなかった。1jaw 群では, 
Table 1 Results compared between cephalometric prediction coordinates and Post treatment coordinates: 1jaw

\begin{tabular}{|c|c|c|c|c|}
\hline & $\begin{array}{c}\text { CP } \\
\text { Mean } \pm \text { S.D. }\end{array}$ & $\begin{array}{c}\text { T2 } \\
\text { Mean } \pm \text { S.D. }\end{array}$ & $\begin{array}{c}\text { difference } \\
\text { Mean } \pm \text { S.D. }\end{array}$ & Wilcoxon \\
\hline measurements & \multicolumn{4}{|c|}{ anteroposterior direction } \\
\hline ANS (mm) & $4.4 \pm 3.3$ & $4.4 \pm 3.3$ & & \\
\hline PNS (mm) & $-49.3 \pm 4.1$ & $-49.3 \pm 4.1$ & & \\
\hline Point A (mm) & $-0.8 \pm 3.8$ & $-0.8 \pm 3.8$ & & \\
\hline Palatal Plane $\left(^{\circ}\right)$ & $1.4 \pm 2.5$ & $1.4 \pm 2.5$ & & \\
\hline $\operatorname{Pog}(\mathrm{mm})$ & $-12.4 \pm 7.3$ & $-14.1 \pm 8.1$ & $-1.7 \pm 2.2$ & NS \\
\hline Go $(\mathrm{mm})$ & $-81.6 \pm 4.5$ & $-79.4 \pm 4.8$ & $2.2 \pm 3.6$ & NS \\
\hline measurements & \multicolumn{4}{|c|}{ vertical direction } \\
\hline ANS (mm) & $29.1 \pm 2.9$ & $29.1 \pm 2.9$ & & \\
\hline PNS (mm) & $28.0 \pm 2.5$ & $28.0 \pm 2.5$ & & \\
\hline Point A (mm) & $35.6 \pm 3.1$ & $35.6 \pm 3.1$ & & \\
\hline Pog $(\mathrm{mm})$ & $95.8 \pm 6.1$ & $95.7 \pm 7.1$ & $-0.5 \pm 1.4$ & NS \\
\hline Go $(\mathrm{mm})$ & $59.8 \pm 8.8$ & $59.1 \pm 8.6$ & $-0.8 \pm 2.4$ & NS \\
\hline
\end{tabular}

Table 2 Results compared between cephalometric prediction coordinates and Post treatment coordinates: 2jaw

\begin{tabular}{crccc}
\hline & CP & T2 & difference & \\
& Mean \pm S.D. & Mean \pm S.D. & Mean \pm S.D. & Wilcoxon \\
\hline measurements & & anteroposterior direction & \\
\hline ANS (mm) & $3.0 \pm 3.6$ & $2.9 \pm 3.2$ & $-0.1 \pm 2.8$ & NS \\
PNS (mm) & $-49.9 \pm 3.1$ & $-49.1 \pm 3.7$ & $0.8 \pm 2.4$ & NS \\
Point A (mm) & $-1.8 \pm 2.8$ & $-1.1 \pm 3.5$ & $0.7 \pm 2.3$ & NS \\
Palatal Plane $\left.{ }^{\circ}\right)$ & $-3.5 \pm 3.8$ & $-3.7 \pm 4.2$ & $-0.2 \pm 3.2$ & NS \\
Pog (mm) & $-13.7 \pm 5.1$ & $-13.6 \pm 7.3$ & $0.1 \pm 5.7$ & NS \\
Go (mm) & $-82.5 \pm 4.5$ & $-79.9 \pm 5.2$ & $2.6 \pm 2.5$ & NS \\
\hline measurements & & vertical direction & \\
\hline ANS (mm) & $24.8 \pm 4.4$ & $23.8 \pm 3.2$ & $-1.1 \pm 3.3$ & NS \\
PNS (mm) & $27.4 \pm 2.8$ & $27.2 \pm 2.8$ & $-0.3 \pm 1.6$ & NS \\
Point A (mm) & $31.1 \pm 3.8$ & $29.3 \pm 3.4$ & $-1.8 \pm 3.6$ & NS \\
Pog (mm) & $96.0 \pm 5.4$ & $95.4 \pm 5.6$ & $-0.6 \pm 3.5$ & NS \\
Go (mm) & $56.8 \pm 4.8$ & $54.1 \pm 6.5$ & $-2.7 \pm 3.9$ & NS \\
\hline
\end{tabular}

Pog は CP に比べ T2 では $1.7 \mathrm{~mm}$ 後方, $0.5 \mathrm{~mm}$ 上方にあり, Go は $2.2 \mathrm{~mm}$ 前方, $0.8 \mathrm{~mm}$ 上方に位置した。2jaw 群では, $\mathrm{Pog}$ は CP に比べ T2 は $0.1 \mathrm{~mm}$ 前方, $0.6 \mathrm{~mm}$ 上方にあり, Go は $2.6 \mathrm{~mm}$ 前方, $2.7 \mathrm{~mm}$ 上方に位置した。

予測移動量と実際の移動量との比較（Table 3) ljaw 群において, Pog, Go のいずれも予測移動量と実
際の移動量の間に有意差を認めなかった（X 軸方向, $\mathrm{Y}$ 軸 方向とも)。2jaw 群では, ANS, PNS, Point A, palatal plane, Pogの計測項目は有意差を認めなかったが, Go で は X 軸方向, $\mathrm{Y}$ 軸方向ともに有意差を認めた。

誤差検定の結果, 計測誤差の最大は, 距離計測項目にお いて $0.24 \mathrm{~mm}$, 角度計測項目において $0.1^{\circ} て ゙ あ り$, 各計測 值は信頼できると考えた。 
Table 3 Result of t-test between planed change (T1-CP) and real change (T1-T2)

\begin{tabular}{|c|c|c|c|c|c|c|}
\hline & \multicolumn{3}{|c|}{ ljaw group } & \multicolumn{3}{|c|}{ 2jaw group } \\
\hline & $\begin{array}{c}\text { T1-CP difference } \\
\text { Mean } \pm \text { S.D. }\end{array}$ & $\begin{array}{c}\text { T1-T2 difference } \\
\text { Mean } \pm \text { S.D. }\end{array}$ & Wilcoxon & $\begin{array}{l}\text { T1-CP difference } \\
\text { Mean } \pm \text { S.D. }\end{array}$ & $\begin{array}{l}\text { T1-T2 difference } \\
\text { Mean } \pm \text { S.D. }\end{array}$ & Wilcoxon \\
\hline measurements & \multicolumn{3}{|c|}{ anteroposterior direction } & \multicolumn{3}{|c|}{ anteroposterior direction } \\
\hline ANS $(\mathrm{mm})$ & & & & $1.5 \pm 2.49$ & $1.6 \pm 1.72$ & NS \\
\hline PNS $(\mathrm{mm})$ & & & & $1.1 \pm 2.29$ & $0.3 \pm 2.08$ & NS \\
\hline Point A (mm) & & & & $0.8 \pm 2.44$ & $0.1 \pm 1.88$ & NS \\
\hline Palatal Plane $\left(^{\circ}\right)$ & & & & $3.1 \pm 3.02$ & $3.3 \pm 2.21$ & NS \\
\hline Pog $(\mathrm{mm})$ & $-6.3 \pm 3.04$ & $-4.6 \pm 2.72$ & NS & $-8.6 \pm 3.38$ & $-8.7 \pm 3.71$ & NS \\
\hline Go $(\mathrm{mm})$ & $-0.8 \pm 2.34$ & $-3.0 \pm 2.63$ & NS & $-0.1 \pm 1.60$ & $-2.8 \pm 2.20$ & $* *$ \\
\hline measurements & \multicolumn{3}{|c|}{ vertical direction } & \multicolumn{3}{|c|}{ vertical direction } \\
\hline ANS (mm) & & & & $2.5 \pm 2.73$ & $3.6 \pm 2.12$ & NS \\
\hline PNS (mm) & & & & $0.1 \pm 2.09$ & $0.4 \pm 1.71$ & NS \\
\hline Point A (mm) & & & & $3.7 \pm 2.92$ & $5.5 \pm 3.89$ & NS \\
\hline Pog $(\mathrm{mm})$ & $-0.5 \pm 1.39$ & $-0.4 \pm 1.66$ & NS & $1.2 \pm 3.30$ & $1.8 \pm 2.75$ & NS \\
\hline Go $(\mathrm{mm})$ & $-0.8 \pm 2.48$ & $-0.2 \pm 1.99$ & NS & $0.1 \pm 1.49$ & $2.9 \pm 3.50$ & $*$ \\
\hline
\end{tabular}

\section{考察}

1. 研究方法について

側貌頭部 X 線規格写真を用いて行われる CP は, 二次 元である側貌頭部 X 線規格写真を用いた分析であるため, 予測可能な範囲は限られている。近年, CBCTやCT, MRIを用いた三次元でのシミュレーションが行われ報 告も多数あるが 25), それらは, 顎矯正手術のシミュレー ションが目的のため, 初診時での治療予測として普及して いるとは言い難い。

また, CP の種類としては手用 $\mathrm{CP}$ と分析ソフトウェア $\mathrm{CP}$ とがある。これらの精度比較を行った研究では, 手用 $\mathrm{CP}$ の精度が分析ソフトゥェア CP と同等もしくは高かっ

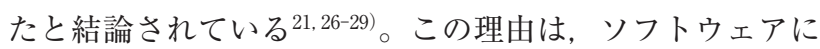
よっては予測に扔いて重要な下䫁骨のオートローテーショ ンを提供しないことによるとされていた。

以上より, 本研究では最も使用されており精度の高い手 用 CP について初診時資料と外科的矯正治療終了時資料を 用いて検討を行うこととした。

なお, 本研究では軟組織の計測は行っていない。患者の 視点で見れば最終的な目標であり重要であるが, そもそも 硬組織に軟組織は付随するのでまずは硬組織の正確な治療 予測が重要であると考え, 本研究では硬組織のみに計測点 を設けた。計測部位は既存のセファロ分析項目を用いず, 座標値をとった。これは上顎骨および下顎骨の動きを少な
い計測項目で簡便かつ効率よく把握するためである。

2. 研究結果について

上顎骨（2jaw 群のみ）における結果について

上顎骨に拀いて T1-T2 と，T1-CP とを比較検討したと ころ, 前方部 (ANS, Point A) について, 前後方向およ び垂直方向とも有意差は認めなかった。後方部（PNS）に ついても, 前後方向抢よび垂直方向とも有意差は認めな かった。Kaipatur ${ }^{9)}$ はすべての研究において, Le Fort I 型骨切り術に扔けるCPによる上顎骨前方部の治療予測 が，実際の顎矯正手術後と比べ有意差が無く良好な予測精 度を示したと述べている。また上顎骨前方部において統計 学的に有意差は認めないものの口腔外科医は上顎骨を治療 予測 CP よりも上方に位置づける傾向があったという。そ して手術時に上顎骨を下方に位置づけるよりも上方に位置 づける方が, 最終的な上顎骨の位置づけは CP と近似し, 上顎骨を上方に位置づけることで下顎が反時計回りの回転 を示し下顎の前方部が上方に位置づけられると報告してい る8, 12,30,31)。本研究においても統計学的な有意差は認めな かったが, 上下顎全ての計測項目において治療後は CP よ りも治療後は上方に位置していた。上顎骨では, 統計学的 有意差はないものの, $\mathrm{CP}$ と比べ外科的矯正治療完了時に ANS, Point A において $1 \mathrm{~mm}$ 以上上方に位置した。一方 PNS は $0.3 \mathrm{~mm}$ 上方であった。ANS と Point A の $1 \mathrm{~mm}$ 以 上の誤差に対して PNS が平均 $0.3 \mathrm{~mm}$ と少ないのは, 本研 究で調べた対象症例は上顎前突症であり全症例上顎骨を反 
時計回りに回転させていることと関係すると考える ${ }^{12)} 。$

下顎骨（1jaw 群，2jaw 群）に扔ける結果について

下顎骨に扔いて $2 \mathrm{jaw}$ 群の予測移動量と実際の移動量の 比較で Go にのみ有意差を認めた。 $\mathrm{CP}, \mathrm{T} 2$ の比較におけ る Goは, 1jaw 群に扔いて前方位, 2jaw 群において前上 方位に位置した。これらの理由として，CP 上では近位骨 片は移動させないが, 実際の顎矯正手術においては, 離断 された近位骨片は咬筋, 内側翼突筋により前上方に移動す るためと考えた。また，1jaw 群では有意差が無く2jaw 群 のみ有意差が生じた理由として，下顎骨の移動のみでな く上顎骨の移動も加わることで移動が複雑となり, 誤差 が大きくなったのではないかと考えた。2jaw 群において は，上顎骨を上方に位置づけることで下顎が反時計回りの 回転を示し Pog が上方に位置づけられるとの報告が多い が 8, 12,30,31), 本研究では, 同様な差は認めなかった。しか し有意差は認めないものの, 1 jaw 群は 2jaw 群と比較し Pogが後方に位置づけられる傾向にあった。この原因とし て顎矯正手術に上顎骨の手術が加わる影響が考えられる が，これについてはさらなる研究が必要と言える。

治療マネージメントの観点からは, Jacobson ら ${ }^{11)}$ は外科 的矯正治療に精通した口腔外科医の選択が $\mathrm{CP}$ の精度を左 右すると述べている ${ }^{11,13)}$ 。CP の精度を上げるためにも, 矯正歯科医と口腔外科医とが良好な協力関係を築き，矯正 歯科医のみではなく双方が治療計画・ CP 立案の段階で関 わっていくべきであり，矯正歯科医は手術術式をよく理解 した無理の無い $\mathrm{CP}$ を立案し, 口腔外科医は CP に沿った 正確な外科手術を施行する事が肝要である ${ }^{8,31) 。 ~}$

本研究結果に扔いて, 外科的矯正治療は初診時 $\mathrm{CP}$ の予 測通り施行されていることが確認できた。しかし本研究 は, 一連の外科的矯正治療全体を通じての治療精度を検討 しており, 術前矯正治療, 顎矯正手術, 術後矯正治療の各 ステージに扔ける予測と治療結果との比較検討を行ってい ない。軟組織の予測を含め, 今後更なる検討を行う必要が あると考える。

\section{結 語}

骨格性上顎前突症における外科的矯正治療において手用 $\mathrm{CP}$ の予測精度は高く, 治療計画の立案時に有用であるこ とが確認された。

\section{文献}

1) Kiyak, H.A., et al.: Self-assessment of profile and body image among orthognathic surgery patients before and two years after surgery. J Oral Maxillofac Surg, $46: 365-371,1988$.

2) Nanda, S.K., et al.: Growth patterns in subjects with long and short faces. Am J Orthod Dentofacial
Orthop. $98: 247-258,1990$.

3) Proffit, W.R., et al.: A comparison of outcomes of orthodontic and surgical-orthodontic treatment of Class II malocclusion in adults. Am J Orthod Dentofacial Orthop, $101: 556-565,1992$.

4) Eckhardt, C.E., et al.: How predictable is orthognathic surgery? Eur J Orthod, 26 : 303-309, 2004.

5) McNeill, R.W., et al.: Cephalometric prediction for orthodontic surgery. Angle Orthod, 42:154-164, 1972.

6) Ricketts, R.M., et al.: The value of cephalometrics and computerized technology. Angle Orthod, 42 : 179, 1972.

7) Bhatia, S.N., et al.: A computer-aided design for orthognathic surgery. Br J Oral Maxillofac Surg, 22 : 237, 1984

8) Wolford, L.M., et al.: Summary of corrections. Wolford, L.M.: Surgical treatment objective, 1st ed.. C.V. mosby Co, St Louis, 1985, p110-112.

9) Kaipatur, N., et al.: Accuracy of computer programs in predicting orthognathic surgery hard tissue response. J Oral Maxillofac Surg, 67 : 1628-1639, 2009.

10) Gossett, C.B., et al.: Prediction accuracy of computerassisted surgical visual treatment objectives as compared with conventional visual treatment objectives. J Oral Maxillofac Surg, 63 : 609, 2005.

11) Jacobson, R., et al.: The predictability of maxillary repositioning in Le Fort I orthognathic surgery. Am J Orthod Dentofacial Orthop, 122:142, 2002.

12) Donatsky, O., et al.: Computerized cephalometric evaluation of orthognathic surgical precision and stability in relation to maxillary superior repositioning combined with mandibular advancement or setback. J Oral Maxillofac Surg, 55 : 1071, 1997.

13) Donatsky, O., et al.: Computerized cephalometric orthognathic surgical simulation, prediction and postoperative evaluation of precision. Int J Oral Maxillofac Surg, 21 : 199, 1992.

14) Semaan, S., et al.: Accuracy of a Le Fort I maxillary osteotomy. Angle Orthod, 75 : 964, 2005.

15) Hillerup, S., et al.: Precision of orthognathic surgery. A computerized cephalometric analysis of $27 \mathrm{pa}-$ tients. Int J Oral Maxillofac Surg, 23 : 255, 1994.

16) Loh, S., et al.: Computer prediction of hard tissue profiles in orthognathic surgery. Int J Adult Orthodon Orthognath Surg, $17: 342,2002$.

17) Loh, S., et al.: A radiographic analysis of computer prediction in conjunction with orthognathic surgery. Int J Oral Maxillofac Surg, $30:$ 259, 2001.

18) Kiyak, H.A., et al.: Psychosocial considerations in surgery and orthodontics. Proffit, W.R.: Surgical orthodontic treatment, 1st ed.. C.V. Mosby Co, St Louis, 1991, p71-89.

19) Kolokitha, O.E., et al.: Cephalometric Methods of Prediction in Orthognathic Surgery. J Maxillofac Oral Surg, $10: 236-245,2011$.

20) Proffit, W.R., et al.: Treatment planning. Optimizing benefit to the patient. Proffit, W.R.: Contemporary 
Treatment of Dentofacial Deformity, 1st ed.. Mosby Year Book, St Louis, 2001, p213-222.

21) Epker, B.N., et al.: Orthodontic-surgical cephalometric prediction tracing. Epker, B.N.: Dentofacial deformities, integrated orthodontic and surgical correction, 2nd ed.. Mosby Year Book, St Louis, 1995, p102-114.

22) Kathnberg, K.E., et al.: Planning and control of vertical dimension in Le Fort I osteotomies. J Craniomaxillofac Surg, 18 : 267-270, 1990.

23) Stanchina, R., et al.: A comparison of two measures for repositioning the maxilla during orthognathic surgery. Int J Adult Orthod Orthogn Surg, $3: 149-$ $154,1988$.

24) Baumrind, S., et al.: The reliability of head film measurements. 2. Conventional angular and linear measurements. Am J Orthod, 60 : 505-517, 1971.

25) Plooij, J.M., et al.: Digital three-dimensional image fusion processes for planning and evaluating orthodontics and orthognathic surgery. A systematic review. Int J Oral Maxillofac Surg, 40:341-352, 2011.

26) Ahmad Akhoundi, M.S., et al.: Comparison of an imaging software and manual prediction of soft tissue changes after orthognathic surgery. J Dent (Tehran), 9:178-187, 2012.

27) Gimenez, C.M., et al.: Cephalometric evaluation of the predictability of bimaxillary surgical-orthodontic treatment outcomes in long face pattern patients: a retrospective study. Dental Press J Orthod, 18 : 5358, 2013.

28) Duclos, P., et al.: Preoperative cephalometric simulation in orthodontic surgery. Rev Stomatol Chir Maxillofac, 92 : 368-372, 1991.

29) Nattestad, A., et al.: Mandibular autorotation in orthognathic surgery: a new method of locating the centre of mandibular rotation and determining its consequence in orthognathic surgery. J Craniomaxillofac Surg, 20 : 163-170, 1992.

30) Ade, L., et al.: Surgical prediction of skeletal and soft tissue changes in treatment of Class II. J Craniomaxillofac Surg, $41:$ 198-203, 2013.

31) West, R.A., et al.: Diagnosis and treatment planning: a coordinated effort between oral and maxillofacial surgery and orthodontics. J Oral Surg, 39:809-816, 1981. 